\title{
Clonality, outer-membrane proteins profile and efflux pump in KPC-producing Enterobacter sp. in Brazil
}

\author{
Juliana Ferraz Rosa', Camila Rizek', Ana Paula Marchi', Thais Guimaraes', Lourdes Miranda², Claudia Carrilho ${ }^{3}$,
} Anna S Levin ${ }^{1}$ and Silvia F Costa ${ }^{4 *}$

\begin{abstract}
Background: Carbapenems resistance in Enterobacter spp. has increased in the last decade, few studies, however, described the mechanisms of resistance in this bacterium. This study evaluated clonality and mechanisms of carbapenems resistance in clinical isolates of Enterobacter spp. identified in three hospitals in Brazil (Hospital A, B and C) over 7-year.
\end{abstract}

Methods: Antibiotics sensitivity, pulsed-field gel electrophoresis (PFGE), PCR for carbapenemase and efflux pump genes were performed for all carbapenems-resistant isolates. Outer-membrane protein (OMP) was evaluated based on PFGE profile.

Results: A total of 130 isolates of Enterobacter spp were analyzed, 44/105 (41, 9\%) E. aerogenes and 8/25 (32,0\%) E. cloacae were resistant to carbapenems. All isolates were susceptible to fosfomycin, polymyxin B and tigecycline. KPC was present in $88.6 \%$ of E. aerogenes and in all E. cloacae resistant to carbapenems. The carbapenems-resistant E. aerogenes identified in hospital A belonged to six clones, however, a predominant clone was identified in this hospital over the study period. There is a predominant clone in Hospital B and Hospital C as well. The mechanisms of resistance to carbapenems differ among subtypes. Most of the isolates co-harbored blaKPC, blaTEM and /or blaCTX associated with decreased or lost of 35-36KDa and or $39 \mathrm{KDa}$ OMP. The efflux pump AcrAB-TolC gene was only identified in carbapenems-resistant E. cloacae.

Conclusions: There was a predominant clone in each hospital suggesting that cross-transmission of carbapenemsresistant Enterobacter spp. was frequent. The isolates presented multiple mechanisms of resistance to carbapenems including OMP alteration.

Keyword: E. aerogenes, E. cloacae, Resistance, Carbapenems, Efflux Pump, Outer Membrane Proteins, $\beta$-lactamases and Activity efflux pump with inhibitor Carbonyl-cyanide-m-chlorophenylhydrazone (CCCP)

\section{Background}

Healthcare associated infections caused by Enterobacter spp. have increased in the last decade all over the world $[1,2]$. Carbapenems are frequently used to treat serious infections caused by multi-resistant Gram-negative bacilli, especially those caused by over production of AmpC cephalosporinases or extended-spectrum $\beta$-lactamases (ESBL), such as infections caused by Enterobacter spp. Thus, the emergence of carbapenems resistance, defined

\footnotetext{
* Correspondence: costasilviaf@ig.com.br

${ }^{4}$ LIM-54, Faculdade de Medicina da Universidade de São Paulo, São Paulo, Brazil Full list of author information is available at the end of the article
}

as resistance to ertapenem, imipenem and/or meropenem, is becoming a therapeutic challenge $[1,2]$.

To date, carbapenemase is the most frequent mechanism of carbapenems resistance reported in Enterobacter spp $[2,3]$. Studies have shown the presence of carbapenameses (blaKPC, blaIMP, blaVIM and blaNDM) in association with ESBL (blaTEM, blaSHV and blaCTX$\mathrm{M})$ in isolates of $E$. aerogenes and $E$. cloacae resistant to carbapenems [2, 3]. Although, E. aerogenes and E. cloacae carbapenems-resistant isolates can decrease and or loss OmpK 35-36 and 39KDa outer membrane proteins (OMPs), which lead to alteration of permeability 
and the induction of active drug efflux AcrAB-tolc, that contribute to resistance to carbapenems [2-6]. However, few studies demonstrated the importance of OMPs and efflux pump on carbapenems resistance in Enterobacter spp $[1,2,7]$.

Therefore, the role of mechanisms of carbapenems resistance, such as OMP and efflux pump in Enterobacter spp, needs to be better addressed. The present study was conducted to investigate the clonality and mechanisms of carbapenems resistance in E. aerogenes and E. cloacae identified in three hospitals in Brazil.

\section{Methods}

\section{Bacteria collection}

One hundred and thirty Enterobacter spp. clinical isolates (105 E. aerogenes and $25 \mathrm{E}$. cloacae) identified in two hospitals (Hospital A and Hospital B whit $30 \mathrm{~km}$ of distance between them) in São Paulo in the state of São Paulo, and one hospital (Hospital C) $530 \mathrm{~km}$ distant, in Londrina in the state of Paraná, Brazil, were evaluated over a 7-year period, from 2005 to 2011.

Although, located in another state, the strains of $E$. cloacae identified in Hospital $\mathrm{C}$ in Londrina were evaluated in order to investigate the mechanism of carbapenems resistance and clonality in this species as well.

The identification of species was performed by API20 E (bioMérieux, France) and additional tests (Modify Rugai, Motility and Lysine).

\section{Clinical data}

The following clinical and demographic data from the medical records of patients hospitalized in Hospital A and Hospital B, were registered: age, gender, underlying diseases, site of infection, length of stay in the Intensive Care Unit and death. Definitions (CDC) for the infections were those used by the Centers for Disease Control and Prevention. An Epi Info ${ }^{\mathrm{m}}$ database was built, and results were expressed as means (standard deviation) or median (interquartile range), depending on normality. All data were analyzed anonymously and confidentially, with approval by the Research Ethics Committee of the three hospitals.

\section{Ethics statement}

The study was performed in two hospitals located in São Paulo, Brazil, the Central Institute of Hospital das Clínicas of University of São Paulo (ICHC-FMUSP) and Hospital Itapecerica da Serra and one hospital in Paraná, the Universitary Hospital in Londrina. It was approved by the ethics committee of the hospitals. The approval number is $007 / 11$.

\section{Susceptible testing}

The minimal inhibitory concentrations (MICs) of imipenem (Merck \& Co. Inc., Elkton, EUA), meropenem (Astra Zeneca), ertapenem (Sigma Chemical, St. Louis, Mo.), cefepime (Bristol-Myers Squibb, Guayaquil, Equador), polymyxin B (Sigma Chemical, St. Louis, Mo.) and tigecycline (Sigma Chemical, St. Louis, Mo.), was performed by broth microdilution with Mueller-Hinton broth. In addition, the MIC of fosfomycin (Sigma Chemical, St. Louis, Mo.) was performed using agar dilution as described in Clinical and Laboratory Standards Institute (CLSI). P. aeruginosa ATCC 27853, E. coli ATTC 25922, S. aureus ATCC 29213 and E. faecalis ATCC 29212, were used as control for all isolates (105 E. aerogenes and $25 E$. cloacae). Carbapenems resistance was defined as: resistance to one or more carbepenems (ertapenem, imipenem and or meropenem) according with CLSI breakpoint.

\section{Carbapenemase genes and efflux pump}

The presence of genes encoding ESBL (blaTEM, blaSHV, blaCTX-M), carbapenemases Class A (blaKPC, blaIMI and blaGES), Class B (blaIMP-1, blaVIM-2, blaGIM -1, blaSPM, blaNDM-1) and Class D (blaOXA-48), was investigated in all isolates (105 E. aerogenes and $25 \mathrm{E}$. cloacae) by PCR as described elsewhere (Table 1) [8-11], genbanks accession numbers: KF285575-KF285585, KY524253 and MTZP00000000.

PCR for all isolates (105 E. aerogenes and 25 E. cloacae) was performed to detect genes of efflux pump acrART using primers according to the study of Perez et al. [12].

DNA sequencing of genes of resistance was performed using the MegaBACE 1000, DNA Analysis System (Amersham Biosciences, UK. England), using DYEnamic ET Dye Terminator Kit (with Thermo Sequence ${ }^{\text {tw }}$ DNA Polymerase II) US81090 code. The sequences were analyzed using the Sequence Analyzer software using the Cimarron Base Caller 3.12. The genetic sequence was compared with the database available on the Internet (BLAST - http://www.ncbi.nlm.nhi.gov/blast/).

\section{Pulsed-field gel electrophoresis}

DNA analysis of all carbapenems-resistant isolates, $44 E$. aerogenes and $8 \mathrm{E}$. cloacae were performed by PFGE, after digestion with XbaI Fast (Invitrogen) and the electrophoretic run was made with the following parameters: $23 \mathrm{~h}$ with pulse times ranging from 5 to $60 \mathrm{~s}$ at $6 \mathrm{~V} / \mathrm{cm}$, using the CHEF-DR III System (Bio-Rad Laboratories, Richmond, CA, USA). DNA relatedness was computationally analyzed using BioNumerics v.7.1 software (Applied Maths, SintMartens-Latem, Belgium). The banding patterns were compared by using the unweighted pair-group method with arithmetic averages (UPGMA), with the Dice similarity coefficient required to be $>80 \%$ for the pattern to be considered as belonging to the same PFGE type (dendrogram). 
Table 1 Primers of all carbapenems resistance genes studied and PCR annealing temperature

\begin{tabular}{|c|c|c|c|}
\hline Primers & Sequences $\left(5^{\prime}-3^{\prime}\right)$ & Annealing temperature & Size $(p b)$ \\
\hline blaTEM - F & TCGCCGCATACACTATTCTCAGAATGA & 55 & 420 \\
\hline blaTEM - R & ACG CTC ACC GGC TCC AGA TTा AT & & \\
\hline blactXM - F & GCT CTAGAATTATTGCATCAGAAA CCGTG & 55 & 893 \\
\hline blactXM - R & CGGAATTCATGATGACTCAGAGCATTGG & & \\
\hline$b^{b l a} \mathrm{OSHV}_{\mathrm{S}}-\mathrm{F}$ & TGCTITGTTAATTCGGGCCAA & 55 & 730 \\
\hline$b l a_{\mathrm{SHV}}-\mathrm{R}$ & ATGCGTTATATTCGCCTGTG & & \\
\hline bla OXA48 - F & GTAACAATGCTTGGTTCG & 55 & 177 \\
\hline bla $a_{\mathrm{OXA48}}-\mathrm{R}$ & TGTTITTGGTGGCATCGA & & \\
\hline blakpc - F & GTTACGCCAAAGGACGAAC & & 893 \\
\hline blakpc - R & TाTCAGAGCCTTACTGCCC & & \\
\hline bla $a_{\text {SPM }}-\mathrm{F}$ & CCTTTTCCGCGACCTTGATC & 59 & 798 \\
\hline$b^{b} a_{S P M}-R$ & ATGCGCTTCATTCACGCAC & & \\
\hline$b l a_{S I M}-F$ & GTACAAGGGATTCGGCATCG & 58 & 569 \\
\hline$b l a_{\mathrm{SIM}}-\mathrm{R}$ & GTACAAGGGATTCGGCATCG & & \\
\hline bla $a_{\mid \mathrm{MP}}-\mathrm{F}$ & TTGGAAAATTATATAATCCC & 47 & 188 \\
\hline$b l a_{I M P}-R$ & CCAAACCACTAGGTTATC & & \\
\hline$b l a_{\mathrm{VIM}}-\mathrm{F}$ & TTTGGTCGCATATCGCAAAG & 60 & 382 \\
\hline bla $a_{\mathrm{VIM}}-\mathrm{R}$ & CCATTCAGCCCAGATCGGCAT & & \\
\hline$b / a_{N D M}-F$ & GGCGGAATGGCTCATCACGA & 60 & 375 \\
\hline bla $a_{N D M}-R$ & CGCAACACAGCCTGACTTTC & & \\
\hline AcrART - F & GAT TAT GAT TCT GCC TTG GCCG & 60 & 130 \\
\hline AcrART - R & CAA TGC GAC CGC TGA TAG GGG & & \\
\hline
\end{tabular}

\section{Outer membrane protein profile}

Based on clonality, the OMP of 22 E. aerogenes isolates and $5 \mathrm{E}$. cloacae isolates were analyzed. Bacterial outer membrane proteins (OMPs) were purified by treatment of the cell envelops with $2 \%$ sodium-N-lauryl sarcosinate (Sigma Chemical.St Louis., MO). The proteins were quantified by the Bradford method with the aid of Bradford reagent (Bio-Rad Laboratories, Brazil) by spectrophotometry at $595 \mathrm{~nm}$ (GeneQuant Pro, GE- Healthcare Life Sciences) and subsequently treated with beta-mercapto-ethanol at a ratio of $2 \mu \mathrm{l}$ acid beta-mercaptoethanol acid to $10 \mu \mathrm{l}$ protein. The proteins studied were applied to polyacrylamide gels prior manufactured $12.5 \%$ (GE Healthcare) at a concentration of $20 \mathrm{ng}$. Electrophoreses run was performed on the Multiphor II device (SG) at $600 \mathrm{~V}, 50 \mathrm{~mA}$, and $30 \mathrm{~W}$ for about $60 \mathrm{~min}$. The following molecular weights were used as markers: 97.4 KDa (phosphorylase B from rat muscle), 66,2KDa (bovine serum albumin), $45 \mathrm{kDa}$ (egg albumin), 31,0KDa (bovine carbonic anhydrase), 21,51KDa (trypsin inhibitor) and $14,4 \mathrm{KDa}$ (lysozyme). Enterobacter aerogenes ATCC13048 was used as control. After electrophoresis, the gel was stained with Silver Staining Kit plus one Kit, Protein (GE Healthcare) according to the manufacturer's instructions. We classified the protein profile based on intensity of band in without lack or loss of protein $(++++)$, very little reduction of protein $(+++)$, reduction $(++)$, major reduction $(+)$ and absent of protein based on previously described by Mostachio et al. [13].

\section{Efflux pump activity}

The efflux pump activity was analyzed based on carbapenems's MIC in 5 E. cloacae that harbored efflux pump gene and 5 in E. aerogenes belonged to different clones. MICs of imipenem, meropenem and ertapenem with 50 and $100 \mathrm{mg} / \mathrm{mL}$ and without the efflux pump inhibitors Carbonyl-cyanide-m-chlorophenylhydrazone (CCCP-Sigma Chemical.St Louis., MO) were determined by agar dilution to investigate the role of efflux pump on carbapenems-resistant E. aerogenes and E. cloacae isolates. The influence of an efflux pump on the carbapenems's MIC for a given bacterial strain was determined by a reduction of at least four-fold of the respective MIC in the presence of CCCP [2].

\section{Results}

A total of $44 / 105(41,9 \%)$ E. aerogenes and 8/25 (32, $0 \%)$ E. cloacae were resistant to carbapenems. Thirtynine isolates of $E$. aerogenes resistant to carbapenems were identified in Hospital A, 5 isolates of E. aerogenes in Hospital $\mathrm{B}$ and 8 isolates of E. cloacae in 
Table 2 In vitro activity of 7 antibiotics against 44 E. aerogenes and 8 E. cloacae carbapenems-resistant strains isolated in three Brazilians hospitals using microdilution and agar dilution

\begin{tabular}{|c|c|c|c|c|c|c|c|}
\hline Antibiotics & Range & CIM 50 (mg/mL) & $\mathrm{CIM} 90$ (mg/mL) & $\%$ resistance & CIM $50(\mathrm{mg} / \mathrm{mL})$ & CIM $90(\mathrm{mg} / \mathrm{mL})$ & $\%$ resistance \\
\hline Imipenem & $0,25-128$ & 8 & 32 & 93,2 & 16 & 64 & 100 \\
\hline Meropenem & $0,25-128$ & 8 & 32 & 93,2 & 16 & 16 & 87,5 \\
\hline Ertapenem & $0,25-128$ & 64 & 128 & 86,4 & 64 & 64 & 100 \\
\hline Tigecycline & $0,03-16$ & 0,25 & 2 & 0 & 1 & 2 & 0 \\
\hline Fosfomycin $^{a}$ & $0,25-256$ & 16 & 64 & 0 & 16 & 32 & 0 \\
\hline Polymyxin B & 0,003-16 & 1 & 2 & 0 & 1 & 2 & 0 \\
\hline Cefepime & $0,25-128$ & $\geq 128$ & $\geq 128$ & 100 & $\geq 128$ & $\geq 128$ & 100 \\
\hline
\end{tabular}

${ }^{\mathrm{a} M I C}$ by agar dilution

Hospital C. E. aerogenes isolates presented MIC ranging from 2 to $128 \mathrm{mg} / \mathrm{ml}$ for imipenem, 4 to $64 \mathrm{mg}$ $/ \mathrm{ml}$ for meropenem and 1 to $\geq 128 \mathrm{mg} / \mathrm{mL}$ for ertapenem. E. cloacae isolates showed MIC ranging from 8 to $64 \mathrm{mg} / \mathrm{ml}$ for imipenem, 2 to $16 \mathrm{mg} / \mathrm{ml}$ for meropenem and 8 to $64 \mathrm{mg} / \mathrm{mL}$ for ertapenem. All isolates were susceptible to fosfomycin, polymyxin B and tigecycline (Table 2).

Demographic and clinical data of 39 patients with colonization and infection caused by $E$. aerogenes resistant to carbapenems in Hospital A and 5 in hospital B are shown in Table 2. Most of the isolates were from blood 12 (30.8\%), followed by 9 (23\%) from respiratory tract secretion and 6 (15.4\%) from urine. Most of patients $(N=17)$ undergone surgery $(4$ liver and 2 kidney transplant), 2 patients received chemotherapy ( 1 acute leukemia and 1 bone marrow transplant) and 1 patient was HIV positive (Table 3). There was no clinical information regarding isolates identified in Hospital C, although, all isolates were from surveillance swabs.

The PCR showed that 39/44 (88.6\%) E. aerogenes isolates harbored bla KPC, other genes encoding carbapenemases were not identified in any isolate. Thirtynine (88.6\%) had blaTEM-1 gene and 41 (93.2\%) blaCTX-M gene. Among the eight isolates of E. cloacae, all harbored blaKPC and blaTEM-1 genes; other carbapenemases studied were not identified.

The outer membrane proteins of 22 of the 44 isolates of $E$. aerogenes and 5 of 8 isolates of $E$. cloacae were analyzed. The intensity of the proteins of interest Omp F (39 KDa) OMP C (42 KDa), 35-36KDa were compared with the molecular weight and ATCC E. aerogenes 13048 was used as control (Table 4).

Table 3 Clinical and demographic characteristics of 39 patients with infection and colonization caused by carbapenems-resistant $E$. aerogenes from Hospital A and 5 patients with colonization and infection caused by carbapenems-resistant E. aerogenes from Hospital B

\begin{tabular}{|c|c|c|}
\hline Patients variables & $\begin{array}{l}\text { Hospital A } \\
N=39(\%)\end{array}$ & $\begin{array}{l}\text { Hospital B } \\
N=5(\%)\end{array}$ \\
\hline Age ( range), mean & $18-87$ years old , 55.6 years old & 24-88 years old, ,58.2 years old \\
\hline \multicolumn{3}{|l|}{ Gender } \\
\hline Female & $13(33,3 \%)$ & 0 \\
\hline Male & $22(56,4 \%)$ & $5(100 \%)$ \\
\hline Length of stay before identification of E. aerogenes (range), mean & $6-190$ days, 43.7 days & 9-17 days, 16.2 days \\
\hline \multicolumn{3}{|l|}{ Site of isolation } \\
\hline Blood & $12(30,8 \%)$ & $1(20 \%)$ \\
\hline Respiratory Tract secretion ${ }^{a}$ & $9(23,1 \%)$ & 0 \\
\hline Urine & $6(15,4 \%)$ & 0 \\
\hline Peritoneal fluid & $3(8 \%)$ & 0 \\
\hline Skin & $2(6 \%)$ & 0 \\
\hline Others & $7(18 \%)$ & $1(20 \%)$ \\
\hline Rectal swab & 0 & $3(60 \%)$ \\
\hline Intensive care unit & $23(59 \%)$ & $3(60 \%)$ \\
\hline Death & $24(61,5 \%)$ & $1(20 \%)$ \\
\hline
\end{tabular}

${ }^{\mathrm{a}}$ Tracheal secretion and Bronco alveolar lavage (BAL) 
Table 4 Minimum inhibitory concentration of carbapenems of 5 carbapenems-resistant $E$. aerogenes and 5 carbapenems-resistant $E$. cloacae isolates by agar dilution with or without efflux inhibitor CCCP

\begin{tabular}{|c|c|c|c|c|c|c|c|c|c|c|c|c|}
\hline \multirow[t]{2}{*}{ Antimicrobial agent } & \multicolumn{6}{|c|}{$\begin{array}{l}\text { E. aerogenes (non-harboring acrART gene) } \\
N=5\end{array}$} & \multicolumn{6}{|c|}{$\begin{array}{l}\text { E. cloacae (harboring acrART gene) } \\
N=5\end{array}$} \\
\hline & \multicolumn{6}{|c|}{$50 \mathrm{mg} / \mathrm{mL}$ CCCP } & \multicolumn{6}{|c|}{$100 \mathrm{mg} / \mathrm{mL}$ CCCP } \\
\hline & \multicolumn{6}{|c|}{$\mathrm{MIC}(\mathrm{mg} / \mathrm{mL}) \mathrm{SD}$} & \multicolumn{5}{|c|}{$\mathrm{MIC}(\mathrm{mg} / \mathrm{mL})$} & SD \\
\hline Imipenem & 8 & 8 & 32 & 64 & 2 & 25,75 & 4 & 8 & 4 & 8 & 32 & 11,79 \\
\hline Imipenem + CCCP & $\leq 0,125$ & $\leq 0,125$ & $\leq 0,125$ & $\leq 0,125$ & 0,25 & 0 & $\leq 0,125$ & $\leq 0,125$ & $\leq 0,125$ & $\leq 0,125$ & $\leq 0,125$ & 0 \\
\hline Meropenem & 4 & 4 & 8 & 32 & 8 & 11,79 & 4 & 4 & 2 & 8 & 16 & 5,58 \\
\hline Meropenem + CCCP & $\leq 0,125$ & $\leq 0,125$ & 1 & $\leq 0,125$ & 1 & 0 & $\leq 0,125$ & $\leq 0,125$ & $\leq 0,125$ & $\leq 0,125$ & $\leq 0,125$ & 0 \\
\hline Ertapenem & 32 & 64 & 32 & 256 & 32 & 93,38 & 16 & 16 & 8 & 32 & 32 & 10,73 \\
\hline Ertapenem + CCCP & $\leq 0,125$ & 2 & $\leq 0,125$ & 2 & 4 & 1,61 & 8 & 8 & $\leq 0,125$ & $\leq 0,125$ & $\leq 0,125$ & 4,35 \\
\hline
\end{tabular}

All isolates harbored KPC

SD standart deviation

The protein profile was classified based on intensity of band in without lack or loss of protein $(++++)$, very little reduction of protein $(+++)$, reduction $(++)$, great reduction $(+)$ and absent (Table 4). All isolates resistant to carbapenems in this study showed a decrease in 35-36 KDa protein. We observed that the $42 \mathrm{KDa}$ protein in our analysis did not appear to be involved in carbapenems resistance.

E. aerogenes isolates with decrease of $39 \mathrm{KDa}$ protein, presented CIM of $2-128 \mathrm{mg} / \mathrm{mL}$ to imipenem, $4-64 \mathrm{mg} / \mathrm{mL}$ to meropenem and 8 a $\geq 128 \mathrm{mg} / \mathrm{mL}$ to ertapenem. Isolates of $E$. aerogenes, which presented absence of $39 \mathrm{KDa}$ protein showed MIC of 8 to $32 \mathrm{mg} / \mathrm{ml}$ for imipenem, 4 to $32 \mathrm{mg} / \mathrm{ml}$ for meropenem and $32-64 \mathrm{mg} / \mathrm{mL}$ to ertapenem.

E. aerogenes isolates with decrease of 35-36 KDa protein, presented MIC of $2-32 \mathrm{mg} / \mathrm{ml}$ for imipenem and 4 to $32 \mathrm{mg} / \mathrm{ml}$ for meropenem and $8-128 \mathrm{mg} / \mathrm{mL}$ to ertapenem. E. aerogenes isolates with absence of the protein of 35-36 KDa showed MIC of $128 \mathrm{mg} / \mathrm{mL}$ to imipenem, $64 \mathrm{mg} / \mathrm{mL}$ to meropenem and $\geq 128 \mathrm{mg} / \mathrm{mL}$ to ertapenem.

Moreover, all isolates of carbapenems-resistant E. cloacae showed decreased of $39 \mathrm{KDa}$ protein and absence of 35-36 KDa protein and their MICs to imipenem were 8 to $64 \mathrm{mg} / \mathrm{ml}, 2$ to $16 \mathrm{mg} / \mathrm{mL}$ to meropenem and $8-64 \mathrm{mg} / \mathrm{mL}$ to ertapenem (Table 5 ).

The PFGE showed 6 clones (A, B, C, E, F and G) among 39 isolates of carbapenems-resistant $E$. aerogenes identified in Hospital A. Clone A was present only in the first two year of study (2005 and 2006), and it was replaced by clone $\mathrm{C}$ that circulated during the entirely study. Twentyseven (69.2\%) isolates belonged to this predominant clone $\mathrm{C}$ that harbored KPC, TEM-1 and CTXM, whose subtypes ranging from $\mathrm{C} 1$ to $\mathrm{C} 19$ over the 7-year study period, from 2005 to 2011 (Fig. 1). Two subtypes (C17 and C19) of clone $\mathrm{C}$ and clone $\mathrm{F}$ were $\mathrm{KPC}$ negative.

The 4 carbapenems-resistant $E$. aerogenes identified in Hospital B belonged to a predominant clone nominated as clone D with subtypes from D1 to D3. This clone harbored KPC and TEM-1, and showed decreased of 39 and 35-36 KDa proteins (Fig. 1 and Table 5).

In addition, the 8 carbapenems-resistant $E$. cloacae identified in Hospital $\mathrm{C}$ in Londrina belonged to two clones, clone A (predominant clone) and clone B (Fig. 2). All carbapenems-resistant E. cloacae isolates harbored KPC, TEM-1 and efflux pump gene acrART (Fig. 2). These clones showed as well lost of 35-36KDa proteins (Table 5).

The efflux pump AcrAB-TolC gene was only identified in carbapenems-resistant E. cloacae. All 5 isolates positive for this efflux pump were resistant to imipenem, meropenem and ertapenem with MICs above $8 \mathrm{mg} / \mathrm{mL}$ for all carbapenems (Tables 4 and 5).

The 5 carbapenems-resistant E. aerogenes isolates belonged to different clones and showed efflux pump activity in presence of CCCP inhibitor. Among the carbapenems-resistant E. cloacae, 2 of the 5 isolates showed efflux pump activity for meropenem, imipenem and ertapenem, and 3 isolates showed no activity on presence of ertapenem (Tables 4 and 5).

\section{Discussion}

In the present study, we demonstrated that all E. aerogenes and E. cloacae isolates resistant to carbapenems were susceptible to polymyxin $\mathrm{B}$, tigecycline and fosfomycin. KPC was the only carbapenemase identified. In contrast with previous studies [5, 10, 14], most of carbapenems-resistant E. aerogenes isolates co-harbored $\mathrm{KPC}$ and wide spectrum ESBL, such as blaTEM and blaCTX-M, in association with alteration of OMPs, mainly reduction or loss of $35-36 \mathrm{KDa}$ and $39 \mathrm{KDa}$ proteins. In addition to alteration of OMPs, E. cloacae isolates harbored blaKPC; blaTEM and efflux pump gene acrART. E. aerogenes isolates were polyclonal, although a different predominant clone was finding in each hospital. On the other hand, E. cloacae belonged to two clones. The mechanisms of resistance to carbapenems 
Table 5 Outer membrane proteins, blaKPC gene, blaTEM and blaCTX and pump efflux (AcrART) profile of 22 carbapenems-resistant isolates of E. aerogenes (hospital A and B) and 5 E. cloacae (hospital C)

\begin{tabular}{|c|c|c|c|c|c|c|c|c|c|c|c|c|}
\hline \multirow[b]{2}{*}{ PFGE } & \multirow[b]{2}{*}{ Hospital } & \multirow[b]{2}{*}{ Date } & \multirow{2}{*}{$\begin{array}{l}\text { Imipenem } \\
\text { MIC }\end{array}$} & \multirow{2}{*}{$\begin{array}{l}\text { Meropenem } \\
\text { MIC }\end{array}$} & \multirow{2}{*}{$\begin{array}{l}\text { Ertapenem } \\
\text { MIC }\end{array}$} & \multicolumn{4}{|l|}{ PCR } & \multicolumn{3}{|c|}{ SDS-PAGE } \\
\hline & & & & & & bla KPC & bla CTX & bla TEM 1 & acrART & $42 \mathrm{KDa}$ & $39 \mathrm{Kda}$ & 35 e $36 \mathrm{KDa}$ \\
\hline$\overline{\mathrm{A} 2}$ & $A$ & $13 / 05 / 2005$ & 32 & 8 & 32 & + & + & + & - & ++++ & +++ & ++ \\
\hline $\mathrm{A} 2$ & A & $10 / 12 / 2005$ & 16 & 8 & 64 & + & + & + & - & ++++ & +++ & ++ \\
\hline C11 & A & $18 / 05 / 2006$ & 32 & 16 & 128 & + & + & + & - & ++++ & +++ & ++ \\
\hline C11 & A & $13 / 07 / 2006$ & 32 & 16 & 128 & + & + & + & - & ++++ & ++++ & ++ \\
\hline C8 & A & $14 / 07 / 2006$ & 16 & 16 & 64 & + & + & + & - & ++++ & ++++ & ++ \\
\hline C7 & A & $02 / 01 / 2007$ & 16 & 4 & 32 & + & + & + & - & ++++ & Absent & ++ \\
\hline C6 & A & 23/03/2007 & 16 & 8 & 64 & + & + & + & - & ++++ & +++ & ++ \\
\hline C13 & A & $25 / 04 / 2007$ & 8 & 4 & 32 & + & + & + & - & +++ & Absent & ++ \\
\hline C14 & A & 21/09/2007 & 8 & 4 & 64 & + & + & + & - & ++++ & +++ & ++ \\
\hline G1 & A & $10 / 11 / 2008$ & 32 & 16 & 64 & + & - & - & - & +++ & Absent & ++ \\
\hline C1 & A & 06/01/2009 & 16 & 32 & 64 & + & - & + & - & +++ & Absent & ++ \\
\hline$C 2$ & A & $31 / 08 / 2009$ & 16 & 4 & 16 & + & + & + & - & +++ & ++ & ++ \\
\hline C4 & A & $03 / 11 / 2009$ & 32 & 16 & 64 & + & + & + & - & +++ & Absent & ++ \\
\hline C5 & A & 29/11/2009 & 16 & 4 & 32 & + & + & + & - & +++ & + & ++ \\
\hline C3 & A & $05 / 12 / 2009$ & 4 & 4 & 16 & + & + & + & - & +++ & ++ & ++ \\
\hline B1 & A & $16 / 03 / 2010$ & 16 & 8 & 64 & + & + & + & - & +++ & Absent & ++ \\
\hline F1 & A & 08/06/2011 & 128 & 64 & $\geq 128$ & + & - & + & - & +++ & ++ & Absent \\
\hline D2 & B & $26 / 12 / 2010$ & 2 & 8 & 32 & + & + & + & - & ++++ & + & ++ \\
\hline D1 & B & 05/01/2011 & 4 & 8 & 32 & + & + & + & - & ++++ & + & ++ \\
\hline D1 & B & 05/01/2011 & 4 & 8 & 32 & + & + & + & - & ++++ & + & ++ \\
\hline D3 & B & 06/01/2011 & 4 & 8 & 8 & + & + & + & - & +++ & + & ++ \\
\hline $\mathrm{A} 2$ & C & $19 / 11 / 2012$ & 8 & 2 & 8 & + & - & + & + & +++ & + & Absent \\
\hline B1 & $C$ & - & 8 & 8 & 64 & + & - & + & + & +++ & + & Absent \\
\hline B1 & C & - & 8 & 8 & 64 & + & - & + & + & +++ & + & Absent \\
\hline A3 & C & - & 64 & 16 & 64 & + & - & + & + & +++ & + & Absent \\
\hline A5 & $C$ & - & 16 & 16 & 64 & + & - & + & + & +++ & + & Absent \\
\hline
\end{tabular}

differed among E. aerogenes subtypes. We identified isolates of $E$. aerogenes resistant to carbapenems that harbored only ESBL (TEM-1 and CTX-M) associated with decreased or loss of 35-36 kDa and $39 \mathrm{kDa}$ proteins.

E. aerogenes and E. cloacae are important agents of healthcare-associated infections in several countries and resistance to carbapenems has been increasing in the last decade, thus there is a need for in vitro studies showing alternatives for the treatment of infections due to these microorganisms $[3,7,14]$. Since our susceptibility results showed that all carbapenems-resistant isolates were susceptible to tigecycline, fosfomycin, and polymyxin B, we consider these findings quite promising. However, it is noteworthy that despite the excellent results in vitro, pharmacokinetics and pharmacodynamics of tigecycline and fosfomycin, and the limited clinical experience in serious infections, especially bloodstream infections, are obstacles to the routine use of these antimicrobials in the treatment of systemic infections. Despite of these drawbacks, these drugs have been used with success as combination therapy in the treatment of severe infections caused by Enterobacteriaceae resistant to carbapenems $[15,16]$.

The demographic and clinical data from the studied hospitals showed that the most frequent site of isolation of carbapenems-resistant Enterobacter was blood, most of our patients had undergone surgical procedures, and had a high overall mortality, similar to previous studies $[14,17]$. The only carbapenemase identified in our study was KPC. Data regarding carbapenems resistance in Enterobacter spp. in Brazil are scarce, although KPC is the carbapenemase most often described in Enterobacter spp. isolates in Brazilians hospitals [5, 7, 14].

Regarding the clonality, we identified in Hospital A, in São Paulo, 6 clones of E. aerogenes, named A, B, C, E, F and $G$ over the study period, from 2005 to 2011, with 


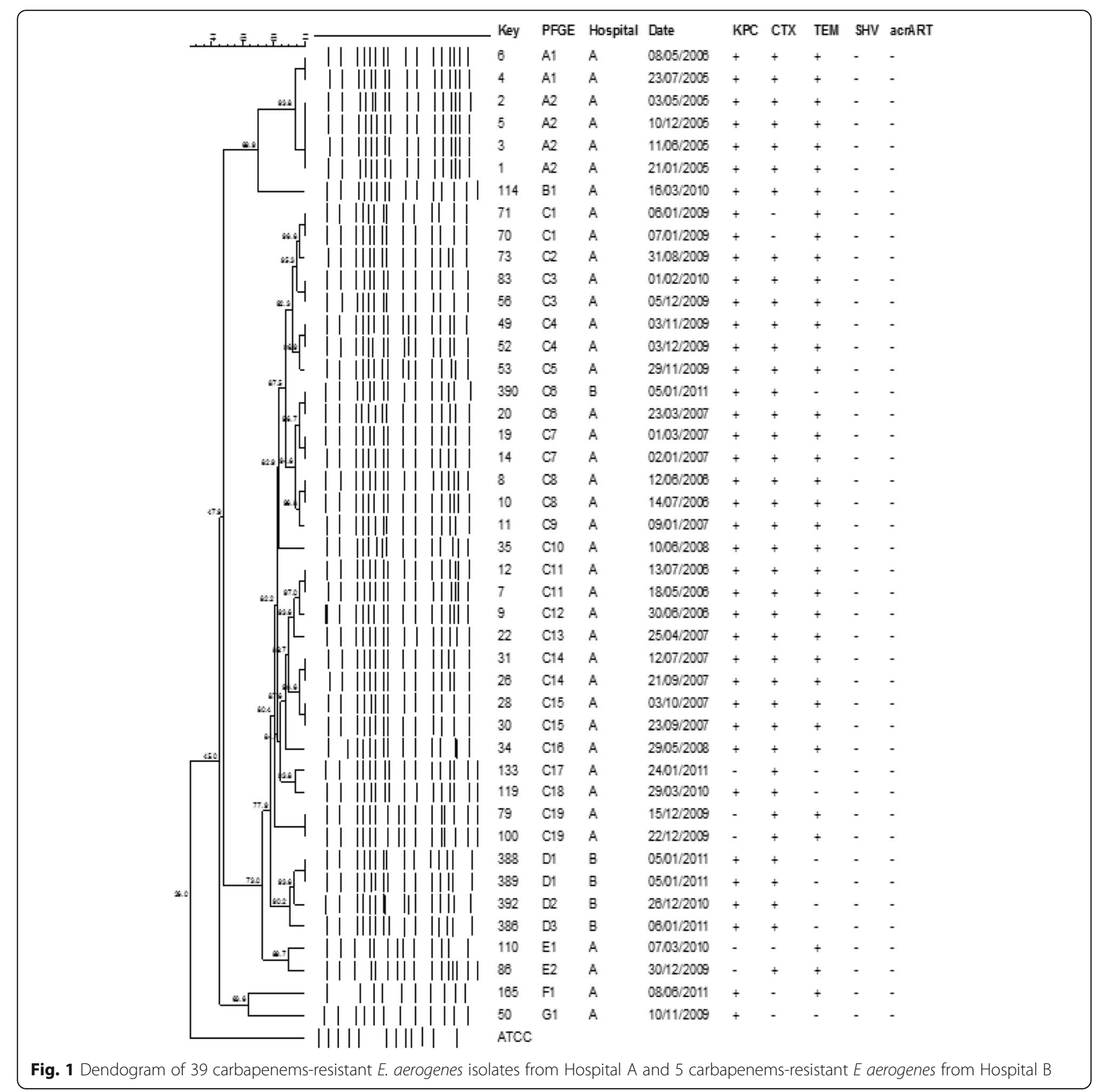

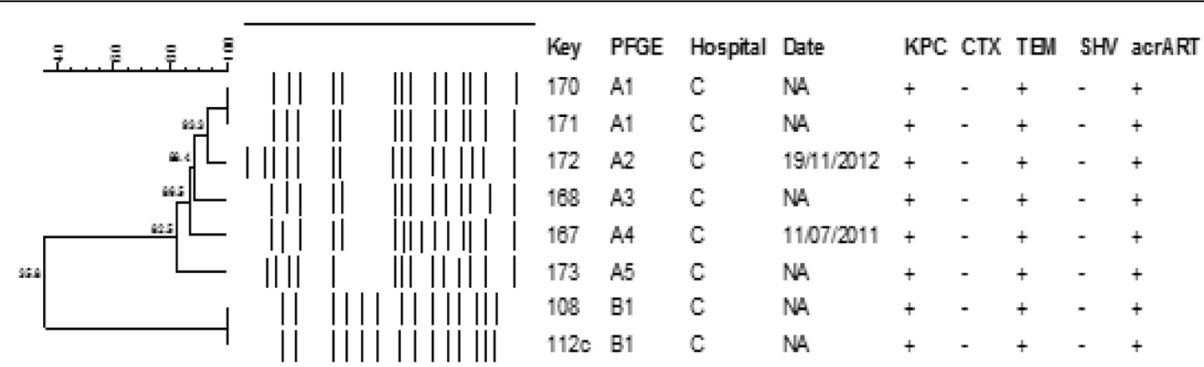

Fig. 2 Dendrogram of 8 carbapenems-resistant E. cloacae isolates from Hospital C 
the predominance of clone $\mathrm{C}$. One predominant clone was also identified in hospital B in São Paulo. An intriguing finding is that one isolate of hospital $B$ seems to be related to a clone of hospital $\mathrm{A}$, pointed to a possible inter-hospital spread. Two clones A (subtypes A1 to A5) and $\mathrm{B}$ were identified among E. cloacae isolates resistant to carbapenems in Hospital $C$, in Londrina, Paraná. These findings suggest that cross-transmissions have occurred over the study period in all hospitals and highlight the importance of the stringent enforcement of hand hygiene and contact precautions to control the spread of this agent. Another interesting finding is that the mechanism of resistance to carbapenems in E. aerogenes from hospital A differs among subtypes and CTX-M was only identified in this hospital.

The profile of outer-membrane proteins of our isolates demonstrated that all isolates studied showed reduction of 35-36 KDa OMPs. These OMPs have been associated with $\beta$-lactam resistance in Enterobacter spp [18-21]. Studies in vivo and in vitro showed that diminished or loss of these OPMS were associated with increase on imipenem and meropenem MIC [18-22]. Other OMPs previously associated with carbapenemsresistance among $E$. aerogenes are OMPs of $42 \mathrm{KDa}$ and OMP of 39KDa [19]. However, in contrast with previous studies, we could not associate the alteration of the $42 \mathrm{KDa} \mathrm{OmpC}$ with carbapenems resistance in our $E$. aerogenes and E. cloacae isolates. This finding could be explained perhaps by the clones that circulated in Brazil. Data regarding OMP in carbapenems-resistant Enterobacter in Brazil is limited. However, a previous Brazilian study demonstrated that $\mathrm{OmpC}$ and $\mathrm{OmpF}$ were present in only $6.6 \%$ of $E$. cloacae isolates resistant to ertapenem [5].

Few authors had evaluated the role of efflux pump on carbapenems resistance in Enterobacter spp [23, 24]. Efflux pump AcrAB system has been described as associated with resistance to meropenem and imipenem in $E$. cloacae [2, 22, 23]. In carbapenems-resistant $E$. aerogenes there were descriptions of efflux pump associated with KPC and/or porin loss as well [2, 23, 24]. In our study, the efflux pump AcrART was found only in E. cloacae. However, eventhough E. aerogenes isolates did not present the efflux pump AcrART gene, carbapenem efflux pump activity was observed in the presence of CCCP inhibitor. Possibly, these E. aerogenes isolates have other efflux pump, not described yet. These findings reinforce the importance of association of mechanism of resistance in carbapenems-resistant Enterobacter spp.

This study has several limitations: besides being retrospective, we evaluated only three hospitals and we could access the clinical data from only two hospitals. However, we were able to demonstrate that there was an association of mechanism of resistance such as $\beta$-lactamase, alteration of outer-membrane protein and efflux pump in carbapenemsresistant Enterobacter spp. in Brazil.

\section{Conclusion}

In conclusion, we observed that there was a predominant clone in each hospital, suggesting that cross-transmission of carbapenems-resistant Enterobacter spp. was frequent. The isolates presented multiple mechanisms of resistance to carbapenems, such as KPC, ESBL and alteration of the outer membrane protein. E. cloacae presented as well the efflux pump AcrART, and in vitro activity of efflux pump inhibitor. These findings can be useful to control the spread of carbapenems resistance among Enterobacter spp. in the hospital setting.

\section{Abbreviations \\ ATCC: American Type Culture Collection; CCCP: Cyanide 3- \\ chlorophenylhydrazone; DNA: Deoxyribonucleic acid; $E$. \\ aerogenes: Enterobacter aerogenes; E. cloacae: Enterobacter cloacae; \\ ESBL: Extended-spectrum $\beta$-lactamases; KPC: Klebsiella pneumonia \\ carbapenemase; M-PCR: Multiplex PCR; NDM: New Deli metallo- $\beta$-lactamase; \\ OMP: Outer-membrane protein; PCR: Polymerase Chain Reaction; PFGE: Pulsed- \\ Field Gel Electrophoresis; VIM: Verona integrin metallo- $\beta$-lactamase}

\section{Acknowledgments}

Not applicable.

\section{Funding}

The study was financial support by CNPQ (Conselho Nacional de Desenvolvimento Científico e Tecnológico) and FAPESP (Fundação de Amparo à pesquisa do Estado de São Paulo, Brazil.

\section{Availability of data and materials}

The datasets supporting the conclusions of this article are available from the www.teses.usp.br/teses/disponiveis/5/5134/tde-11012016-142655/pt-br.php

\section{Authors' contributions}

JFR and SFC designed the study. JFR, LM, CC, TG, ASL and SFC collected the samples. JFR, CR and APM carried out the laboratory work. JFR, TG, ASL and SFC analyzed the data. JFR and SFC wrote the manuscript. All authors read and approved the final version of manuscript.

\section{Competing interests}

The authors declare that they have no competing interests.

\section{Consent for publication}

Not applicable.

\section{Ethics approval and consent to participate}

All data were analyzed anonymously and confidentially, with approval by the Research Ethics Committee of the three hospitals, the approval number is 007/11. It was a retrospective study, thus, it was not possible to apply the consent to participate.

The study was performed in two hospitals located in São Paulo, Brazil, the Central Institute of Hospital das Clínicas of University of São Paulo (ICHCFMUSP) and Hospital Itapecerica da Serra and one hospital in Paraná, the Universitary Hospital in Londrina. It was approved by the ethics committee of the hospitals. The approval number is $007 / 11$.

\section{Publisher's Note}

Springer Nature remains neutral with regard to jurisdictional claims in published maps and institutional affiliations.

\section{Author details}

${ }^{1}$ Department of Infectious Diseases, University of São Paulo, Laboratory of Medical Investigation 54 (LIM-54), Hospital Das Clínicas FMUSP, São Paulo, Brazil. ${ }^{2}$ Hospital de Itapecerica da Serra, Itapecerica da Serra, SP, Brazil. 
${ }^{3}$ Hospital University of Londrina, Londrina, Paraná, Brazil. ${ }^{4}$ LIM-54, Faculdade de Medicina da Universidade de São Paulo, São Paulo, Brazil.

Received: 21 September 2016 Accepted: 4 March 2017 Published online: 17 March 2017

\section{References}

1. Bratu S, Landman D, Alam M, Tolentino E, Quale J. Detection of KPC carbapenem-hydrolyzing enzymes in Enterobacter spp. from Brooklyn, New York. Antimicrob Agents Chemother. 2005;49:776-8.

2. Qin X, Yang Y, Hu F, Zhu D. Hospital clonal dissemination of Enterobacter aerogenes producing carbapenemase KPC-2 in a Chinese teaching hospital. J Med Microbiol. 2014;63:222-8.

3. Davin-Regli A, Pages JM. Enterobacter aerogenes and Enterobacter cloacae; versatile bacterial pathogens confronting antibiotic treatment. Front Microbiol. 2015;6:392.

4. Doumith M, Ellington MJ, Livermore DM, Woodford N. Molecular mechanisms disrupting porin expression in ertapenem-resistant Klebsiella and Enterobacter spp. clinical isolates from the UK. J Antimicrob Chemother. 2009:4:659-67.

5. Jaskulski MR, Medeiros BC, Borges JV, Zalewsky R, Fonseca ME, Marinowic DR, et al. Assessment of extended-spectrum beta-lactamase, KPC carbapenemase and porin resistance mechanisms in clinical samples of Klebsiella pneumoniae and Enterobacter spp. Int J Antimicrob Agents. 2013;1:76-9.

6. Pérez A, Canle D, Latasa C, Poza M, Beceiro A, Tomás M d, et al. Cloning, nucleotide sequencing, and analysis of the AcrAB-TolC efflux pump of Enterobacter cloacae and determination of its involvement in antibiotic resistance in a clinical isolate. Antimicrob Agents Chemother. 2007;51:3247-53.

7. Tavares CP, Pereira PS, Marques EA, Faria Jr C, de Almeida R, et al. Molecular epidemiology of KPC-2-producing Enterobacteriaceae (non-Klebsiella pneumoniae) isolated from Brazil. Diagn Microbiol Infect Dis. 2015;82:326-30.

8. Kim SY, Park YJ, Yu JK, Kim HS, Park YS, Yoon JB, et al. Prevalence and mechanisms of decreased susceptibility to carbapenems in Klebsiella pneumoniae isolates. Diagn Microbiol Infect Dis. 2007;1:85-91.

9. Chen Y, Zhou Z, Jiang Y, Yu Y. Emergence of NDM-1-producing Acinetobacter baumannii in China. J Antimicrob Chemother. 2011;6:1255-9.

10. Chen Z, Li H, Feng J, Li Y, Chen X, Guo X, et al. NDM-1 encoded by a pNDM-BJ01-like plasmid p3SP-NDM in clinical Enterobacter aerogenes. Front Microbiol. 2015;6:294.

11. Monteiro J, Widen RH, Pignatari AC, Kubasek C, Silbert S. Rapid detection of carbapenemase genes by multiplex real-time PCR. J Antimicrob Chemother. 2012;67:906-9.

12. Pérez $A$, Poza M, Fernández A, Fernández MC, Mallo S, Merino M, et al. Involvement of the AcrAB-TolC efflux pump in the resistance, fitness, and virulence of Enterobacter cloacae. Antimicrob Agents Chemother. 2012;56:2084-90.

13. Mostachio AK, Levin AS, Rizek C, Rossi F, Zerbini J, Costa SF. High prevalence of OXA-143 and alteration of outer membrane proteins in carbapenem-resistant Acinetobacter spp. isolates in Brazil. Int J Antimicrob Agents. 2012;5:396-401.

14. Tuon FF, Scharf C, Rocha JL, Cieslinsk J, Becker GN, Arend LN. KPCproducing Enterobacter aerogenes infection. Braz J Infect Dis. 2015;19:324-7.

15. Entenza JM, Moreillon P. Tigecycline in combination with other antimicrobials: a review of in vitro, animal and case report studies. Int J Antimicrob Agents. 2009;1:8.e1-9.

16. Datta S, Roy S, Chatterjee S, Saha A, Sen B, Pal T, Som T, Basu S. A five-year experience of carbapenem resistance in Enterobacteriaceae causing neonatal septicaemia: predominance of NDM-1. PLoS One. 2014;11:e112101.

17. De Gheldre Y, Struelens MJ, Glupczynski Y, De Mol P, Maes N, Nonhoff C, et al. National epidemiologic surveys of Enterobacter aerogenes in Belgian hospitals from 1996 to 1998. J Clin Microbiol. 2001;3:889-96.

18. Thiolas A, Bornet C, Davin-Regli A, Pages JM, Bollet C. Resistance to imipenem, cefepime, and cefpirome associated with mutation in Omp36 osmoporin of Enterobacter aerogenes. Biochem Biophys Res Commun. 2004;317:851-6.

19. Yigit $H$, Anderson GJ, Biddle JW, Steward CD, Rasheed JK, Valera LL, et al. Carbapenem resistance in a clinical isolate of Enterobacter aerogenes is associated with decreased expression of $\mathrm{OmpF}$ and $\mathrm{OmpC}$ porin analogs. Antimicrob Agents Chemother. 2002;46:3817-22.
20. Lavigne JP, Sotto A, Nicolas-Chanoine MH, Bouziges N, Pages JM, DavinRegli A. An adaptive response of Enterobacter aerogenes to imipenem: regulation of porin balance in clinical isolates. Int J Antimicrob Agents. 2013:41:130-6.

21. Lavigne JP, Sotto A, Nicolas-Chanoine MH, Bouziges N, Bourg G, Davin-Regli A. Membrane permeability, a pivotal function involved in antibiotic resistance and virulence in Enterobacter aerogenes clinical isolates. Clin Microbiol Infect. 2012;18:539-45.

22. Wozniak A, Villagra NA, Undabarrena A, Gallardo N, Keller N, Moraga M, et al. Porin alterations present in non-carbapenemase-producing Enterobacteriaceae with high and intermediate levels of carbapenem resistance in Chile. J Med Microbiol. 2012;61:1270-9.

23. Philippe N, Maigre L, Santini S, Pinet E, Claverie JM, Davin-Régli AV, et al. In vivo evolution of bacterial resistance in two cases of Enterobacter aerogenes Infections during treatment with imipenem. PLoS One. 2015;10: e0138828.

24. Bornet $C$, Chollet R, Malléa M, Chevalier J, Davin-Regli A, Pagès JM, Bollet $C$. Imipenem and expression of multidrug efflux pump in Enterobacter aerogenes. Biochem Biophys Res Commun. 2003;301(4):985-90.

\section{Submit your next manuscript to BioMed Central and we will help you at every step:}

- We accept pre-submission inquiries

- Our selector tool helps you to find the most relevant journal

- We provide round the clock customer support

- Convenient online submission

- Thorough peer review

- Inclusion in PubMed and all major indexing services

- Maximum visibility for your research

Submit your manuscript at www.biomedcentral.com/submit
Biomed Central 